\title{
DE NOORSE ZENDING IN ZOELOELAND (1879-1890)
}

\section{C. de Jong}

HET Historisch Instituut van de M.O.-lerarenopleiding aan de Universiteit van Trondheim in Noorwegen heeft een groot projekt „Noorse zending in Afrika” aangepakt. Leider daarvan is dr. Jarle Simensen, schrijver van o.m. het boek History of Africa (1970) en studiepromotor van een groeiend aantal verhandelingen over delen van zijn projekt.

De Noorse zending in Afrika is gelokaliseerd in Zuid-Afrika (hoofdzakelijk Zoeloeland) en op Madagascar. Zij heeft baanbrekerswerk verricht in Zoeloeland; haar grote apostel daar was bisschop Hans P. S. Schreuder (1817-82). Wegens onbekendheid met de Skandinavische talen is men in Zuid-Afrika weinig over de Skandinavische, o.m. de Noorse, zending ingelicht en wordt haar betekenis onderschat ondanks de grote hoeveelheid gepubliceerd en ongepubliceerd materiaal in Skandinavië aanwezig.

De eerste, ongepubliceerde, verhandeling over de Noorse zending, welke door de Universiteit van Trondheim in 1973 goedgekeurd is, was van Endre Sönstabö en is getiteld Fortropper for europeisk imperialisme: Norske misjonaerer $i$ Zululand 1850-1880. ${ }^{1}$ De tweede is een vervolg en kritiek op de magistersverhandeling van Sönstabö. Zij is van Thomas Magnus Börhaug en getiteld Imperialismens kollaboratörer? En analyse av norske misjonaerers holdning og rolle under den europeiske etableringsfase $i$ Zululand 1873-1890 (258 pp., ongepubliceerd), ${ }^{2}$ goedgekeurd in 1976 . Ook van dit werk is publikatie van een Engelse vertaling in Zuid-Afrika aan te bevelen.

De hedendaagse Europese geschiedschrijving is meer dan de Zuid-afrikaanse beïnvloed door sociale, economische en volkenkundige gezichtspunten. Dat merkt men in de twee bovengenoemde verhandelingen. Terwijl Zuidafrikaanse geschiedwerken over Zoeloeland voornamelijk de politieke staatkunde bespreken en daardoor onvermijdelijk aan de oppervlakte blijven, dringen de twee Noren door tot de economische en andere achtergronden en geven aldus een beter inzicht in de verwarde inwendige strijd in Zoeloeland tussen 1879 en 1890.

Sönstabö zet uiteen, dat het Zoeloerijk onder het huis van Shaka berustte op het oude sibbeverband (sibbe is de grote familie, Duits „Sippe”, Schots „clan”) met voorouderverering en veelwijverij en met de despotie als nieuw element door Shaka ingevoerd als bijkomende samənbinding. Sönstabŏ beschrijft verdienstelijk het Zoeloerijk als een min of meer gesloten, zelfgenoegzame volkshuishouding zonder markten en in- en uitvoer van betekenis. ${ }^{3}$ De Zoeloevorsten lieten onder druk van die Britse regering schoorvoetend eerst Noorse en daarna andere zendelingen in hun rijk toe, maar 
verboden overgang tot het Christendom, zodat tot de oorlog in 1879 de zending geen voet aan de grond kreeg.

Om de weerstand tegen het zendingswerk weg te nemen wensten de Skandinavische zendelingen verbreking van de despotie en het sibbeverband. Daardoor zou de Zoeloe-enkeling niet meer onderhorig aan zijn vorst en sibbe zi n, open staan voor kerstening, geldverkeer en zucht naar bezit, een hoger ontwikkelings- en welvaartspeil kunnen bereiken en een welgesteld Christenburger kunnen worden, zo redeneerden de meeste Noorse zendelingen.

Sönstabö schrijft, dat met dit doel voor ogen alle Noorse zendelingen geporteerd waren voor de onderwerping van Zoeloeland door de Britten en voor verdrijving van het huis van Shaka. Volgens hem waren deze zendelingen handlangers van het Britse imperialisme. Hij keurt deze aantasting van de onafhankelijkheid en cultuur der Zoeloes af in de trant van de hendendaagse antikapitalistische, anti-imperialistische, antikoloniale en anti-Westerse stroming. Hij kritiseert in het bijzonder bisschop Schreuder scherp, omdat de Zoeloes hem als hun pleitbezorger en als Cetswayo's vertrouweling beschouwden, doch hij speelde dubbel spel en verried hen aan de Britse autoriteiten.

Börhaug kritiseert Sönstabös ongunstige, ongenuanceerde oordeel over de Noorse zendelingen. Zijn magistersverhandeling beschrijft hun houding in de troebele jaren 1879-90, toen burgeroorlog tussen aanhangers en tegenstanders van het huis van Shaka Zoeloeland in beroering hield. Hij overdrijft waarschijnlijk de schade door de oorlog in 1879 (de Britse verovering) aangericht, maar niet de schade van tien jaar burger- en sluipoorlog, welke daarna volgden. De Britse commissaris Wolseley verdeelde het veroverde Zoeloeland in dertien staatjes; de hoofden daarvan, onder wie John Dunn, ontnamen de "usuthu" - dat waren de hoeders en vruchtgebruikers van de koninklijke kudden en aanhangers van het huis van Shaka - hun vee en weiveld en schiepen aldus aanleiding tot voortdurende conflicten. De verdeling in dertien staatjes belemmerde voorts in hoge mate de verplaatsing van vee van zomer- naar winterweide en terug. De vestiging van Transvaalse boeren in het gebied, waar spoedig de Nieuwe Republiek en de "proviso" ontstonden, veroorzaakte mededinging tussen de schaapskudden der Boeren en het rundvee der Zoeloes om weiveld. Aldus verklaart Börhaug de onrust in Zoeloeland.

Daarbij kwam, dat na de oorlog in 1879 Zoeloeland werd opengesteld voor Westerse landbouw en handel. Transvalers namen er grond in bezit en Natalse handelaren vestigden er handelszaken; een van hen was de later bekende Noorse immigrant Jacob J. Egeland te Durban. De hoofden der dertien staatjes, onder wie Usibebu en Dunn de invloedrijkste waren, gaven graag licenties aan handelaren, deden zaken met hen, presten hun afhangelingen door hutbelasting tot leverantie van produkten en arbeid en hieven belasting van Zoeloes, die wegens armoede in Natal gingen werken. Börhaug noemt die hoofden uitbuiters en kiest vooral Dunn als doelwit van zijn afkeuring.

$\mathrm{Hij}$ toont meer begrip voor de moeilijke positie der weinig 
bemiddelde Noorse zendelingen tijdens de troebele tien jaar en voor hun verlangen naar veiligheid voor hun gezin, persoon en eigendom en naar onbelemmerd zendingwerk. De meesten van hen wensten daarom annexatie van Zoeloeland door de Britse regering, en toen deze jarenlang aarzelde het machtsvacuum te vullen, naar bezetting door de Boeren. Maar hij betoogt, dat sommige Noorse zendelingen een geheel afwijkend standpunt innamen en dat Sönstabös oordeel over hen veel te weinig genuanceerd is. Hij neemt het dan ook op voor Schreuder. Deze maakte beslist voorbehoud jegens het Britse iimperialisme in Zoeloeland, hij wenste neutraal bemiddelaar tussen Cetswayo en de Britse autoriteiten te zijn en handelde daarnaar. Börhaug beklemtoont, dat Schreuder daarom nooit het vertrouwen van Cetswayo en de Zoeloes heeft verloren. Dat bleek uit Cetswayo's opdracht om Schreuders zendingsstation Entumeni en de Christen-Zoeloes daar te sparen, terwijl alle andere zendingsstations in 1879 zi $n$ verwoest. Persoonlijk heb ik in Zoeloeland vernomen, dat Schreuder ook nu nog een bijkans legendarisch respekt geniet.

Börhaug corrigeert op p. 91 Sönstabös mededeling, dat Cetswayo op verzoek van Shepstone in 1873 aan Schreuder Entumeni in eigendom heeft gegeven in afwijking van het stamrecht. Dat was Schreuders versie van deze overdracht; Cetswayo heeft ze slechts onder druk van Shepstone toegestaan en Wolseley heeft geweigerd ze te erkennen.

Volgens Börhaug (p. 73) beoogde Schreuder een vrede met herstel van Cetswayo als vorst over het onverdeelde Zoeloeland onder Brits protektoraat met vrije toelating van de zending en van bekering, dus geen annexatie en geen verdeling van Zoeloeland. Daarom beschouwden de Zoeloes Schreuder als loyaal. Enige andere Noorse zendelingen deelden zijn standpunt. Zij waren Schreuders opvolger Nils Astrup, die bisschop Colenso's waardering voor de Zoeloes deelde, en één zendeling, Lars Larsen, van het Noorse Zendinggenootschap te Stavanger, waarvan Schreuder zich in 1873 had afgescheiden. De andere zendelingen van Stavanger keurden het Britse imperialisme goed, met voorbehoud evenwel inzake te geringe faciliteiten voor de zending vóór de Britse annexatie van Zoeloeland in 1887.

Börhaug schetst het conflict over die faciliteiten. Wolseley had de dertien opvolgers van Cetswayo verboden om grond aan blanken in eigendom te geven en gemachtigd om het sibbe- en stamverband te handhaven. Dit besluit stelde de zendelingen teleur en bracht hen in botsing met de dertien hoofden, in de eerste plaats Dunn, die het meeste op zijn rechten stond. Het conflict eindigde met vergelijk en verzoening tussen Dunn en de zendelingen, uitgezonderd de onbuigzame Schreuder op Entumeni, die echter in 1882 overleed. Dunn was daarna zeer tegemoetkomend, in het bijzonder jegens de Noorse zending.

Börhaug neemt Cetswayo en Schreuder in bescherming, doch kritiseert Wolseley, die niet met Schreuder overweg kon, en Dunn. Hij vermeldt weliswaar Dunns steun aan onderwijs en scholen van de Noorse zending in zijn gebied en aan sommige Westerse 
tradities (uitgezonderd de veelwijverij, welke Dunn zelf ijverig beoefende), maar hij verklaart deze steun uit Dunns zelfzuchtige motieven. Hij beoordeelt aldus Dunn met de ethische maatstaf van onze tijd en niet vanuit 19de-eeuwse opvatting, volgens welke Dunn echt niet een van de slechtste blanken was.

Börhaug verklaart ook de welwillende houding der zendelingen, vooral die van Stavanger, jegens het opdringen der Transvalers in Zoeloeland in 1879-87 en de stichting der Nieuwe Republiek. $\mathrm{Hij}$ onthoudt zich echter van de afkeuring van deze actie door de meeste Engelstalige schrijvers. De eenzame Larsen kwam onder het gezag van de Nieuwe Republiek, dat hij evenals Astrup wantrouwde. Börhaug besluit zijn verhandeling met een hoofdstuk over de annexatie onder de ironische titel ,Zegening der beschaving” en verbindt de annexatie symbolisch met de dood van Larsen als kampvechter van de nationale zaak der Zoeloes. Börhaug noemt het een ironie der geschiedenis, dat bij Larsens begrafenis het eerbetoon werd geleverd door de Boeren, die Larsen altijd heeft gewantrouwd.

Ook inzake de bedrijvigheid van blanke handelaren in Zoeloeland verschilden de Noorse zendelingen onderling van mening. Sommigen juichten die bedrijvigheid toe in het belang van de produktie voor de markt en geregelde loonarbeid door Zoeloes, m.a.w. van de commercialisering van het Zoeloevolk. De zendelingen Ommund en Christian Oftebro dreven handel en wierven arbeiders voor Natal. Anderen, o.a. Nils Astrup, maakten nadrukkelijk voorbehoud, omdat zij niet alleen over de geestelijke, maar ook de stoffelijke belangen van het Zoeloevolk wilden waken, en zij kozen dan ook dikwijls de partij der Zoeloes tegen blanke handelaren en boeren. In 1887 zond het Stavangerse genootschap secretaris $O$. Gjerlöw uit om het zendingswerk te inspekteren. Hij keurde de economische bedrijvigheid van sommige zendelingen in Zoeloeland sterk af, verving 0 . Oftebro als voorzitter der zendelingenconferenties en ontsloeg C. Oftebro terstond.

Börhaug verklaart op p. 143 de pro-Zoeloe-gezindheid van vele zendelingen uit de invloed van The Aborigenes Protection Society in Brittannië. Astrup werd bovendien beïnvloed door bisschop Colenso's pleidooien voor het huis van Shaka en een onafhankelijk Zoeloeland. Deze Noorse zendelingen waren scherpe kritici van de Engelssprekende en vooral van de Afrikaner kolonisten en stelden hen voor als vijanden van de zending en uitbuiters van de gekleurden.

Börhaug heeft een duidelijk en boeiend beeld van de moeilijkheden en standpunten der Noorse zendelingen in Zoeloeland in 1879-90 gegeven. Zijn kollega Per Hernaes zal het volgende tijdperk 1890-1910 beschrijven, o.m. de Noorse zending tijdens het eerste naspel van de ondergang van het Zoeloerijk, dat is de actie der Zoeloes tegen de Transvalers in de Tweede AngloBoerenoorlog (o.m. de moord bij Holkrans in Mei 1902), en tijdens het tweede naspel, de Bambata-opstand in 1906.

Bronnen: Tenslotte een opmerking over bronnen voor het hier besproken projekt van het Historisch Instituut in Trondheim. Tot dusver hebben de medewerkers van het instituut in Trondheim 
gepubliceerde bronnen en ongepubliceerde in Noorwegen gebruikt. Het is spijtig dat zij wel toegang tot het archief van Schreuders zendingsgenootschap in Oslo hebben gekregen, maar niet tot het archief van het Stavangers genootschap, temeer daar de in Noorwegen gepubliceerde bronnen, zoals de jubileumgeschriften der genootschappen en de vele jaargangen van het tijdschrift van het Stavangerse genootschap, Norsk Missions-Tidende, uiteraard een eenzijdig beeld der zendingsbedrijvigheid geven. Ook andere zendingsgenootschappen buiten Noorwegen, welke in Zuid-Afrika werkzaam waren, hebben meermalen aan historici toegang geweigerd wegens interne moeilijkheden, want niet alle zendelingen waren heilige mannen en conflicten tussen zendingsbesturen in Europa en de arbeiders op het verre, weinig bekende zendingsveld overzee kwamen meermalen voor.

Aanvulling van het uitgebreide, goed geordende materiaal in Skandinavië met archiefonderzoek in Zuid-Afrika is voor het Trondheimse projekt wenselijk, maar vermoedelijk moeilijk. $\mathrm{Na}$ een vluchtig onderzoek heb ik de indruk, dat de meeste bronnen in Skandinavische talen luiden en in Skandinavië zijn, goed bewaard, hoewel niet altijd in de archieven toegankelijk. Materiaal onder de vrij talrijke nakomelingen van Noorse zendelingen in ZuidAfrika schijnt schaars te zijn. Overblijven ambtelijke stukken in Natal en Londen en de Natalse nieuwsbladen. Het doorgaan hiervan is mogelijk, doch tijdrovend werk.

1 Zie het besprekingsartikel „Zending en imperialisme (1)" door C. de Jong aan E. Sônstabös werk gewijd in "In die Skriflig", Jaargang 12, Nr. 46, Junie 1978.

2 Sinds Wereldoorlog II heeft het woord collaborateur in Noorwegen, Nederland en andere landen, welke door Duitsland bezet waren, de ongunstige betekenis van handlanger van de nationale vijand.

3 Deze "collective or traditional economy" is beschreven door o.a. S. Viljoen in zijn boek Economic systems in world history, Longman, Londen 1974, p. $\mathbf{1 - 2 2}$. 